\title{
The Effect of Conflicts in Organizational Sectors in Pakistan
}

\author{
Muhammad Umair, Sara Aslam, Habiba Yousaf \\ Department of Business Administration, University of Sargodha, Sargodha, Punjab, Pakistan
}

Email address:

Mumair342@yahoo.com (M. Umair)

\section{To cite this article:}

Muhammad Umair, Sara Aslam, Habiba Yousaf. The Effect of Conflicts in Organizational Sectors in Pakistan. Science, Technology \& Public Policy. Vol. 2, No. 1, 2018, pp. 1-4. doi: 10.11648/j.stpp.20180201.11

Received: May 5, 2018; Accepted: June 1, 2018; Published: June 14, 2018

\begin{abstract}
This paper investigates the reason of organization conflicts and how to overcome? For this purpose, we select manufacturing sector and service sector in Pakistan. We collect the primary data and apply Descriptive statistics for achieving the objectives. According to our findings, conflicts are not good for organization. So in manufacturing sector, the main reasons of conflicts are communication channels, breach of trust, employees clashes and lack of skill, and experience. It can be remove through define the proper goals, compromise with employees and develop trust with management and employees. In service sector the most appropriate reasons of conflicts are undefined goals, clashes between employees and management communication barriers rules and lack of resources. So both sectors have to develop appropriate strategy for overcoming it because according to our findings it's not healthy for organizations.
\end{abstract}

Keywords: Conflicts, Manufacturing Sector, Service Sector, Pakistan, Descriptive Statistics

\section{Introduction}

In today era, an organization tries to enhance their performance by resolving the multiple hurdles like conflicts. Different Conflicts situations arise for individuals and for groups as well. Conflicts are considered as a tool of bad management and organization tries to be escaped from conflicts as early as possible, when the goals of an organization are not achievable the conflicts may arises among managers, staff individuals and in groups, conflicts are unavoidable and offensive reality of an organization occurs due to the lack of resources, behavior regulations, ambiguous jurisdiction, communication barriers, disagreeing patterns, force and fear. Usually conflicts has two aspects positive and negative, positive conflicts encourage innovativeness of employees, and polish interpersonal skills of employees, while negative conflicts occurs due to missunderstanding of someone behavior, philosophies, regulations and ambiguous patterns and cause disrespect and distrust among managers and staff. The presence of conflicts within the organization defines that employees are competent, innovative, motivated and tries to enhance the performance of organization while absence of conflicts defines that employees are not competent to change they are de-motivators. The leaders should tries to adopt positive conflicts as an opportunity and try to resolve negative conflicts by considering them as a risk. It is a fact that conflicts are un-ignorable, the services firms and manufacturing firms usually face "conflict of interest" that's defines a situation which is good for an individual and bad for other individuals.

Now this study is composed of following parts. First is impact of conflicts with different variables, second is research objective third is methodology fourth is analysis and fifth is conclusion.

\section{Literature Review}

Conflict among workers have inevitable in any organization, it can be useful if it manage properly and efficient manner. In case of mismanagement conflicts can creates serious problem for organization. Numerous literature have exist in the world which proof that some places conflicts improve the organization performance and some places conflicts creates the serious problem for organization. Cacciattolo, (2015) Explain the two aspects of politics one is the positive of organization and other is the harmful for organization. Brandenberger, (2007) Conduct study and this study do not support the specific behavior that can be the 
cause of conflict. Moreover, according to this study $98 \%$ respondance are claimed that some conflicts are healthy.

(Mwangi \& Ragui, (2013) Check the impact of conflict on air transport and concluded that poor management can impact on employee's performance and give the suggestion that if air transport improve itself then have to focus on sound management strategy.

Hotepo, Asokere, \& Azeez, (2010) See the effects of conflicts on the performance of organization by applying descriptive research method and conclude that mostly conflict areas due to the insufficient, resources so if this situation manages properly then employees motivated and organizational performance increase. AJIKE, AKINLABI, MAGAJI, \& SONUBI, (2015) Check the effect of conflicts on the financial sectors in Nigeria by applying regression and descriptive analysis they prove the positive and significant relation of conflicts and financial sectors in Nigeria. Longe, (2015) Investigate the impact of work place conflict management on organizational performance by applying descriptive and inferential techniques and also prove the positive connection between variables non-integrative conflicts and suggested that conflicts can minimize if appropriate strategies adopted by management of the organization. Henry, (2009) Say about conflicts that the major reason of conflicts are limited resources.

Moreover, Eunice, Jacqueline, Buyeke, Wafula, \& Musyoki, (2015) says about internal personal conflicts and it impact on organization performance that Various strategies of conflicts and relationship conflict and task conflict significantly affect organizational performance but interpersonal conflicts have not significantly link with organizational performance. Garcia, (2013) Suggest to management that, they should create friendly and learning environment for employee's due to these, employees encourage and organizational performance will improve. Omisore \& Abiodun, (2014) says that conflicts areas due to the competition, leadership styles and scarce resources. So, it is the responsibility of management to overcome it as soon as possible otherwise it create the alarming situations for the organization.

Particularly, the situation of conflict prevails where task assigned by concern authority to its subordinates. According to De Dreu \& Weingart, (2003) prove the strongly negative correlation between conflicts and team performance and the satisfaction of the member of the team. Donkor, Afriyie, Danquah, \& Nimsah, (2015) Say that task and process conflicts have motivated to employees and organization perform according to favorable manner. Every sector have affect due to the conflict it may be manufacturing sector or service sector or even health and scientific sector so for investigating in health and scientific sector study finds that, $16 \%$ conflict of interest policies have affected in 1997.

NAKADA, (2006) Says that conflict may happenings due to the non-response behavior of others if public have silence then it seems like that no conflict exist but in actual, situation is quite opposite. Conflict is a dynamic factor and exist every sector and every place where social interaction is possible.
Michelsen, (2009) Says that, in case of agriculture sectors the reason of conflict is to mismatching the financial transposition. According to opinion inter branch conflicts play a vital role for understanding the political situations in America. Thus, it proves that, due to the conflict, some positive benefits can be achieved.

A conflict prevails due to the change in policies so for understanding the variations and analysis then have to focus on supplementary institutional approaches Stewart, (2006). According to NECK \& DOCKNER, (1987) the central bank and government can achieve the targets more efficiency and effectively way by cooperating with each other. So if they cooperate then conflict will areas, so they tackle negative issues.

Alemu, (2018) Investigate in southern Ethiopia and argue that conflict management is one of the prominent factor in organization. According to him, conflicts are not suitable for organization and also find the main reason of conflicts is communication channel. Organizational performance can be improve if organizations avoid conflicts. Another investigation Chigozie, (2017) argues that unclear responsibility, poor reward system and lack of group interest are responsible factors of conflicts. Jokanović, Tomić, \& Duđak, (2017) Works on organizational conflicts resolution and conclude that, clash of ideas and communication are responsible factors of conflicts. According to them, different personalities play an important role to handle conflicts.

Moreover, Awan \& Saeed, (2015) investigate in banking sector of Pakistan by applying descriptive technique and ratio analysis (for financial performance) and conclude that conflict management strategies have significantly affect towards the organizational performance so if management want to improve the performance of the organization, then have to make the appropriate strategies for resolving the conflicts.

Conflicts prevails every sectors such as communities, personal conflicts and international conflicts. The main focus of this study is to explain the reason of conflicts and investigate either conflicts are useful or harmful.

\section{Research Objective}

Following are the main motives of the study.

1) What are the reasons of conflict in manufacturing sector?

2) What are the reasons of conflicts in services sectors in Pakistan?

3) What are the appropriate tools for resolving?

\section{Data Collection and Methodology}

In order to achieve the above objectives, we choose manufacturing sectors and services sectors in Pakistan. Survey technique was adopted and questioner data was used to answer the above objective. In questioner we ask the opinion and suggestions about conflicts and its solution 
because there can be many cases and many solution in the mind of employees.

\section{Result}

First purpose of this study was to investigate the conflicts involvement in secleted sectors.

\begin{tabular}{lll}
\multicolumn{3}{c}{ table 1. Conflicts involvement. } \\
\hline & Manufacturing sector & Service sector \\
\hline Conflict involvement & $100 \%$ & $80 \%$ \\
\hline
\end{tabular}

According to available information from our respondances $100 \%$ conflict involve in manufacturing sector and $80 \%$ in Service sector. Furthermore, our next result about impact of conflict on the organization.

Second purpose of this study was to investigate the impact of conflicts on manufacturing and service sectors.

Table 2. Impact of conflicts.

\begin{tabular}{lll}
\hline & Manufacturing sector & Service sector \\
\hline Positive impact & $30 \%$ & $41 \%$ \\
\hline
\end{tabular}

According to above information it is prove that just $30 \%$ have positive impact on manufacturing sector and just $41 \%$ in service sector.

So for the overcome, first of all we have to know about the reasons of conflicts according to the employee's opinion through questioner.

Table 3. Conflict Reasons in Manufacturing Sector.

\begin{tabular}{lll}
\hline Sr. & Reasons of conflict & \% of response \\
\hline 1 & Communication barriers & $75 \%$ \\
2 & Interference of govt. policies & $40 \%$ \\
3 & Negative Behaviour & $25 \%$ \\
4 & Fevourisum & $50 \%$ \\
5 & Organizational rules & $10 \%$ \\
6 & Undefined Goals & $56 \%$ \\
7 & Breach of trust & $68 \%$ \\
8 & Personal clashes between employees and & $61 \%$ \\
9 & management & $7 \%$ \\
10 & Rewards and compensation & $64 \%$ \\
11 & Lersonal clashes between employees to & $14 \%$ \\
12 & Lack of Experience & $71 \%$ \\
13 & Lack of Skill & $67 \%$ \\
14 & Lack of resources & $25 \%$ \\
15 & improper check and balance & $50 \%$ \\
16 & Centralized system & $18 \%$ \\
\hline
\end{tabular}

Source: adapted from Henry,(2009)

Above table shows the reason of conflicts and \% show the agree of employees each question. According to our analysis, lack of experience, lack of skills, breach of trust and personal clashes among employee's and there executives are prominent causes of conflicts in manufacturing sectors.
Table 4. Conflict Solution in Manufacturing Sector.

\begin{tabular}{lll}
\hline & Solution & \% of response \\
\hline 1 & Improvement in communication & $50 \%$ \\
2 & Friendly Behaviour of Management & $25 \%$ \\
3 & Proper define goals & $75 \%$ \\
4 & Compromising & $60 \%$ \\
5 & Avoiding & $22 \%$ \\
6 & Build trust with subordinates & $70 \%$ \\
7 & Avoid crustal issues & $25 \%$ \\
8 & Conflict can be useful tool for organization & $30 \%$ \\
\hline
\end{tabular}

Source: adapted from Henry,(2009)

This table shows the suggestions of conflict according to the employee's perceptions. According to them conflict can be minimize if organizations define proper goals, build friendly conditions at work place and compromise with top level and subordinates.

Table 5. Conflict in Service Sector.

\begin{tabular}{lll}
\hline Sr. & Reasons of conflict & \% of response \\
\hline 1 & Communication barriers & $50 \%$ \\
5 & Organizational rules & $57 \%$ \\
6 & Undefined Goals & $73 \%$ \\
7 & Breach of trust & $42 \%$ \\
8 & Personal clashes between employees and & $77 \%$ \\
& management & \\
10 & Personal clashes between employees to & $54 \%$ \\
11 & employees & $38 \%$ \\
12 & Lack of Knowledge & $29 \%$ \\
13 & Lack of Experience & $33 \%$ \\
14 & Lack of Skill & $59 \%$ \\
\hline
\end{tabular}

Source: adapted from Henry,(2009)

Above table shows the reasons of conflict in service sector of pakistan, according to our analysis, communication barriers, organizational rules, clashes are more important factors of connflicts.

Table 6. Conflict Solution in Service Sector.

\begin{tabular}{lll}
\hline & Solution & \% of response \\
\hline 1 & Improvement in communication & $70 \%$ \\
2 & Friendly Behaviour of Management & $68 \%$ \\
3 & Proper define goals & $22 \%$ \\
4 & Compromising & $29 \%$ \\
5 & Avoiding & $6 \%$ \\
6 & Build trust with subordinates & $65 \%$ \\
8 & Conflict can be useful tool for organization & $25 \%$ \\
\hline
\end{tabular}

Source: adapted from Henry,(2009)

According to employee's perception the most prominent solution of conflicts in services sector is to immprove communication channel and remain friendlhy and build friendly relation with each other and subordinates. If organization focus on obove factors, then communicaiton barriers can be minimized. 


\section{Conclusion}

The aim of this study was to identifies the reasons and overcome of conflicts in manufacturing sector and services sector in Pakistan.

Because our resopndnace are not agree the effect of conflicts in organization. So, for the better performance and better management, it is necessary to find out the reasons and suggestions according to the employee's point of view.

Our finding shows that the major reasons of conflicts in manufacturing sector are communication channels, favourism breach of trust, employee's clashes and lack of skill, and experience so for overcome on these reasons, management have to make proper strategy for overcoming these issues and define the proper goals, compromise with employees and develop trust with management and employees as well.

In service sector mostly reasons of conflicts are undefined goals, clashes between employees and management communication barriers, rules and lack of resources so management have to make appropriate strategy for overcome it.

\section{References}

[1] AJIKE, E. O., AKINLABI, B. H., MAGAJI, N., \& SONUBI, A. O. (2015). EFFECT OF CONFLICT MANAGEMENT ON THE PERFORMANCE OF FINANCIAL SERVICE ORGANISATION IN NIGERIA: AN EMPIRICAL STUDY OF ACCESS BANK PLC. International Journal of Economics, Commerce and Management, 260-272.

[2] Awan, A. G., \& Saeed, S. (2015). Conflict Management and Organizational Performance: A Case Study of Askari Bank Ltd. Research Journal of Finance and Accounting, 88-102.

[3] Alemu, L. (2018). Organizational Conflict Management Strategies of Hotel Sectors in Ethiopia: Employees Perception on the Practices in Case of Selected Hotels in Wolaita Sodo Town, Southern Ethiopia. The International Journal Of Business \& Management, 10-16.

[4] Carter, J. J. (2000). INTERBRANCH CONFLICT AND THE EARLY EVOLUTION OF COVERT ACTION AS A PRESIDENTIAL TOOL OF FOREIGN POLICY. Southeastern Political Review, 599-629.

[5] Chigozie, N. E. (2017). Impact of Organizational Conflict on Employee Job Performance in Selected Hotels (in Lagos Nigeria). TURIZAM, 45-64.

[6] De Dreu, C. K., \& Weingart, L. R. (2003). Task Versus Relationship Conflict, Team Performance and Team Member Satisfaction: A Meta-Analysis. Journal of Applied Psychology, 741-749.

[7] Donkor, P., Afriyie, S., Danquah, B. A., \& Nimsah, W. K. (2015). Effect of Conflict on Employees Performance Evidence from Coca Cola Company Limited, Kumasi Branch. American Scientific Research Journal for Engineering, Technology, and Sciences, 44-53.
[8] Eunice, M., Jacqueline, K., Buyeke, E., Wafula, M., \& Musyoki, J. (2015). Effects of interpersonal conflict on organisational performance in selected hotels in Kisiitown. African Journal of Hospitality, Tourism and Leisure, 1-15.

[9] Garcia, M. P. (2013). Organizational Conflict and Organizational Performance. Asian Educational Research Association, 41-45.

[10] Henry, O. (2009). Organisational conflicts and its effects on organisational performance. Research journal of business management, 16-24.

[11] Hotepo, O. M., Asokere, A. S., \& Azeez, I. A. (2010). Empirical Study of the Effect of Conflict on Organizational Performance in Nigeria. Business and Economics Journal, 19.

[12] Jokanović, B., Tomić, I., \& Duđak, L. (2017). Organizational conflict resolution. XVII International Scientific Conference on Industrial Systems (IS'17), 446-451.

[13] Krimsky, S., \& Rothenberg, L. S. (2001). Conflicts of Interest Policies in Science and Medical journals: Editorial Practices and Author Disclosures. Science and Engineering Ethics, 205218.

[14] Longe, O. (2015). Impact of Workplace Conflict Management on Organizational Performance: A Case of Nigerian Manufacturing Firm. Journal of Management and Strategy, 83-92.

[15] Michelsen, J. (2009). The Europeanization of organic agriculture and conflicts over agricultural policy. Food Policy $34,252-257$.

[16] NAKADA, M. (2006). Distributional Conflicts and the Timing of Environmental Policy. International Environmental Agreements, 29-38.

[17] NECK, R., \& DOCKNER, E. (1987). CONFLICI AND COOPERATION IN A MODEL OF STABILIZATION POLICIES. Journal of Economic Dynamics and Control 11, 153-158.

[18] Omisore, B. O., \& Abiodun, A. R. (2014). Organizational Conflicts: Causes, Effects and Remedies. International Journal of Academic Research in Economics and Management Sciences, 118-137.

[19] Stewart, J. (2006). Value Conflict and Policy Change. Review of Policy Research, 183-195.

[20] Brandenberger, A. J. (2007). Relationship Conflict: The Good, the Bad, and the Ugly. Advances in Communication Theory \& Research, 1-22.

[21] Cacciattolo, K. (2015). ORGANISATIONAL POLITICS: THE POSITIVE \& NEGATIVE SIDES. European Scientific Journal, 121-129.

[22] Mwangi, C., \& Ragui, M. (2013). Effects of work place conflicts on employee performance in the air transport industry in Kenya. Prime Journal of Business Administration and Management (BAM), 1083-1089. 